\title{
ANALISIS MINAT WISATA ROHANI DI CANDI HATI KUDUS GANJURAN
}

\author{
Hery Krestanto \\ Dosen Akademi Pariwisata Yogyakarta \\ email: herychrestanto@ymail.com
}

\begin{abstract}
The purpose of this study was to determine the interest in spiritual tourism in tyas palace temple sacred heart Ganjuran, the research was conducted in the temple sacred heart Ganjuran tyas palace.

Tyas temple sacred heart Ganjuran Ganjuran located in Bantul district of Yogyakarta as a special propinsidaerah Dutch heritage, inculturation Hindu temple has a Buddhist, Javanese, Europe, inculturation Hindu temple and a Buddhist look of relief created, while the Java ikulturasi visible from carnival procession Perwita cider, ikulturasi europe seen from the cross of the existing

The technique of collecting data using interviews and observations, research results show an interest in spiritual travel temple palace Ganjuran tyas there who believe that the essence Perwita water can cure various diseases, find a mate and other petition, people who come to the temple tyas palace is not only a religious Ganjuran Catholic but of various religions such as Islam, Hinduism, Buddhism, they come like getting wangsi the purpose
\end{abstract}

Keyword : Minat, Wisata Rohani, Candi Hati kudus,

\section{PENDAHULUAN}

Indonesia memiliki kekayaan alam yang berlimpah yaitu berpuluh ribu pulau, beraneka ragam bentuk alam, budaya yang unik, peninggalan - peninggalan bersejarah serta suku adat istiadat, dan kesenian yang beragam. Dengan demikian indonesia di jadikan sebagai negara dengan daerah tujuan wisata yang dikenal dunia.

Yogyakarta adalah salah satu propinsi sebagai daerah tujuan wisata yang secara history banyak sekali peninggalan bersejarah seperti kraton, benteng vandeberg, pantai parang tritis, pantai glagah dan tak kalah pentingnya peninggalan-peninggalan yang dapat digunakan sebagai tempat berdoa. Salah satu peninggalan bersejarah dengan ikulturasi budaya seperti candi tyas dalem hati kudus ganjuran ini juga banyak dikunjungi dan bahkan menurut sumber yang saya terima mereka belum tahu candi tyas dalem hati kudus ganjuran tetapi ada yang menggerakkan hati untuk datang kesana dan mengunjungi candi hati kudus ganjuran karena kekuatan aneh yang menyuruh mereka datang ke candi, setelah mereka datang kesana ada hal muzijat yang mereka dapatkan dan akhirnya berita itu sampai kemana mana dan orang berbondong bondong datang ke candi Hati kudus ganjuran, minat merupakan faktor psikologis yang dapat menentukan suatu pilihan pada seseorang dan tertarik untuk melihat, menjalani. Dari latar belakang ini maka saya tertarik untuk membuat judul 
analisis minat wisata rohani di candi hati kudus tyas dalem ganjuran

\section{LANDASAN TEORI}

Guna mencapai tujuan penelitian di perlukan ladasan teori berikut akan disampaikan landasan teori

\section{Pengertian minat}

Minat adalah kecenderungan yang agak menetap dalam subjek untuk merasa tertarik pada bidang atau hal tertentu dan merasa senang berkencimpung dalam bidang tersebut, pada dasarnya seseorang yang mempunyai minat yang tinggi akan mencapai hasil yang maksimal. Hal tersebut disebabkan oleh faktor-faktor yang mempengaruhi minat. Faktorfaktor yang mempengaruhi minat dikelompokkan menjadi dua golongan (Winkel , 1986):

\section{a. Minat secara intrinsik}

Minat secara intrinsik merupakan minta yang berdasarkan suatu dorongan yang secara mutlak timbul dari dalam individu sendiri tanpa ada pengaruh dari luar

b. Minat Secara ektrinsik merupakan minat yang berdasarkan suatu dorongan atau pengaruh dari luar individu

Minat diartikan sebagai kehendak, keinginan atau kesukaan (Kamisa, 1997). Minat adalah sesuatu yang pribadi dan berhubungan erat dengan sikap. Minat dan sikap merupakan dasar bagi prasangka, dan minat juga penting dalam mengambil keputusan. Minat dapat menyebabkan seseorang giat melakukan menuju ke sesuatu yang telah menarik minatnya. (Gunarso,1995). Minat merupakan sumber motivasi yang mendorong orang untuk melakukan apa yang mereka inginkan bila mereka bebas memilih (Hurlock, 1995).

Minat terbagi menjadi 3 aspek, yaitu: (Hurlock, 1995)

\section{a. Aspek Kognitif}

Berdasarkan atas pengalaman pribadi dan apa yang pernah dipelajari baik di rumah, sekolah dan masyarakat serta dan berbagai jenis media massa.

b. Aspek Afektif

Konsep yang membangun aspek kognitif, minat dinyatakan dalam sikap terhadap kegiatan yang ditimbulkan minat.Berkembang dari pengalaman pribadi dari sikap orang yang penting yaitu orang tua, guru dan teman sebaya terhadap kegiatan yang berkaitan dengan minat tersebut dan dari sikap yang dinyatakan atau tersirat dalam berbagai bentuk media massa terhadap kegiatan itu.

c. Aspek Psikomotor

Berjalan dengan lancar tanpa perlu pemikiran lagi, urutannya tepat. Namun kemajuan tetap memungkinkan sehingga keluwesan dan keunggulan meningkat meskipun ini semua berjalan lambat.

\section{Macam minat}

Minat dibedakan menjadi 2 yaitu: (Witherington, 1999)

a. Minat primitif

Disebut pula minat biologis, yaitu minat yang berkisar soal makanan dan kebebasan aktifitas.

b. Minat kultural

Disebut juga minat sosial yaitu minat yang berasal dari perbuatan yang lebih tinggi tarafnya.

\section{Kriteria Minat}

Menurut Nursalam (2003), minat 

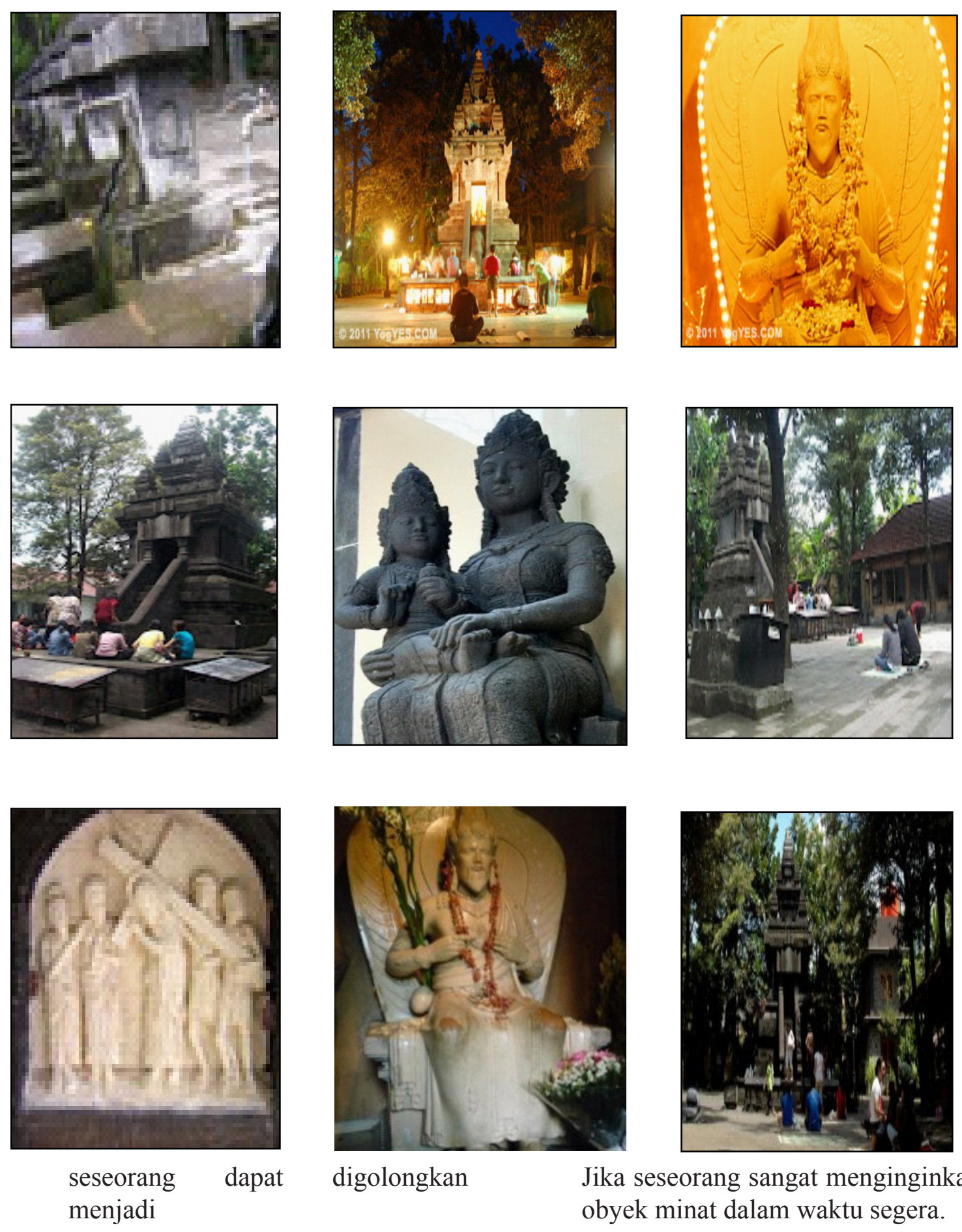

digolongkan

Jika seseorang sangat menginginkan obyek minat dalam waktu segera.

a. Rendah

Jika seseorang tidak menginginkan obyek minat

b. Sedang

Jika seseorang menginginkan obyek minat akan tetapi tidak dalam waktu segera.

c. Tinggi

\section{Beberapa kondisi yang mempengaruhi} minat

a. Status ekonomi

Apabila status ekonomi membaik, orang cenderung memperluas minat mereka untuk mencakup hal yang semula belum mampu mereka laksanakan. Sebaliknya kalau status 
ekonomi mengalami kemunduran karena tanggung jawab keluarga atau usaha yang kurang maju, maka orang cenderung untuk mempersempit minat mereka.

\section{b. Pendidikan}

Semakin tinggi dan semakin formal tingkat pendidikan yang dimiliki seseorang maka semakin besar pula kegiatan yang bersifat intelek yang dilakukan. Seperti yang dikutip Notoatmojo, 1997 dari L.W. Green mengatakan bahwa "Jika ada seseorang yang mempunyai pengetahuan yang baik, maka ia mencari pelayanan yang lebih kompeten atau lebih aman baginya". Kurangnya pengetahuan masyarakat mengenai pelayanan kesehatan akan mempengaruhi pemanfaatan fasilitas pelayanan yang ada sehingga berpengaruh pada kondisi kesehatan mereka.

\section{c. Tempat tinggal}

Dimana orang tinggal banyak dipengaruhi oleh keinginan yang biasamereka penuhi pada kehidupan sebelumnya masih dapat dilakukanatau tidak.

Faktor-faktor utama yang mempengaruhi minat seseorang (Yuwono, 2001)

d. Kondisi pekerjaan

Tempat kerja yang memiliki suasana yang menyenangkan dengan didukung oleh kerja sama yang profesional, saling bantu dapat meningkatkan produksi.

e. Sistem pendukung

Dalam bekerja sangat diperlukan sistem pendukung yang memadai

bagi para pekerjanya sehingga diperoleh hasil produksi yang maksimal, misalnya fasilitas kendaraan, perlengkapan pekerjaan yang memadai, kesempatan promosi, kenaikan pangkat/kedudukan.

f. Pribadi pekerja

Semangat kerja, pandangan pekerja terhadap pekerjaannya, kebanggan memakai atribut bekerja, sikap terhadap pekerjaannya.

\section{Cara menimbulkan minat}

Minat dapat ditimbulkan dengan cara: (Effendi dan Praja, 1993)

g. Membangkitkan suatu kebutuhan.

h. Menghubungkan dengan pengalaman yang lampau.

i. Memberikan kesempatan untuk mendapat hasil yang lebih baik

\section{Pengertian Wisata}

Menurut jenisnya pariwisata dibedakan menjadi tiga kelompok besar berdasarkan klasifikasi objeknya dan daya tarik Wisata (Undang-undang Kepariwisataan nomor 9 tahun 1990 pasal 4 dan 6) Yaitu Wisata Budaya (Cultural tourism ), wisata alam (Natural tourism ) dan wisata minat khusus (Special interes tourism)

a. Wisata budaya ( Cultural tourism ) adalah jenis wisata yang memanfaatkan potensi hasil budaya manusia sebagai objek dan daya tarik nya, untuk indonesia objek wisata jenis budaya ini paling diminati oleh wisatawan asing, jenis wisata budaya meliputi:

1) Wisata cagar budaya / arkeologis (candi-candi,situs situs purba kala )

2) Wisata histori / sejarah (Peninggalan bekas bersejarah , kraton, musium ) 
3) Wisata religius (Candi borobudur, prambanan , pura masjid, candi hati kudus tyas dalem ganjuran, masdjid, makam orang suci/ besar)

4) Wisata seni (Wayang kulit , salawatan, balet, ramayana, kethoprak, dolalak, kuda lumping)

5) Wisata kerajinan (Batik, topeng, gerabah, kerajinan perak kota gede )

6) Wisata boga (Makanan tradisional seperti gethuk sokaraja, getuk magelang, geplak bantul, lumpia semarang, wingko badad semarang )

7) Wisata ritual / upacara tradisioanal (sekaten, grebeg, labuhan, saparan, malam satu suro, sedekah laut, )

b. Wisata alam (natural tourism) adalah jenis wisata yang memanfatkan potensi alam sebagai objek daya tariknya . jenis wisata alam meliputi :

1) Wisata dataran tinggi ( Hawa sejuk, lingkungan alam, dan pemandangan indah )

2) Wisata cagar alam ( dunia flora dan fauna yang dilindungi perilaku kehidupan satwa )

3) Wisata hutan ( hutan lindung, taman nasional )

4) Wisata gua (gua kiskendo, gua selarong)

5) Wisata tirta (sungai pindul, sungai elo, sungai progo )

c. Wisata minat khusus ( special iterest tourism ) adalah jenis wisata yang memanfaatkan potensi khusus sebagai objek daya tariknya, jenis wisata khusus meliputi :
1) Wisata konvensi

2) Wisata olahraga

3) Wisata industri

4) Wisata kesehatan

5) Wisata bulan madu

6) Wisata kampus

\section{Wisata rohani / berziarah}

Berziarah meliputi :

a. Doa matiraga

Doa merupakan upaya manusia berusaha komunikasi dengan tuhannya, dengan sumber hidupnya, dengan yang maha kudus, karena merasa terpanggil, didekati olehnya, disentuh diberkat, sementara manusia menyadari ketidak pantasnya, tetapi tertarik, merasa membutuhkan, ingin menghadap maka biasanya orang membersihkan diri, dan lalu bermati raga, bercerah diri sendiri dan menyadari dirinya bersalah, tidak pantas karena hawa nafsunya hasratnya yang tidak layak dihadapan sang maha suci

b. Dengan perjalan ketempat suci

Tempat suci termasuk kuburan orang tua atau nenek moyang atau orang suci. Orang sebenarnya ingin dekat dengan sang maha suci. Suatu tempet tertentu dianggap tempat suci dimana sang maha suci dengan cara tertentu dialami orang yang ada disitu Kubur orang diziarahi karena dianggap yang sudah meninggal dapat diminta menjadi perantara. Sementara orang sering berpikir pintas ( tidak salah ) yang sudah meninggal pantas didekati sebagai ungkapan cinta dan hormatnya

c. Dengan intensi khusus / ujub 
Ujub ditandai oleh sifat mendesak dan kesungguhan hati, dapat dikatakan dari sisi mendesaknya kebutuhan orang maka dari itu juga membuat orang bermohon dengan sangat lagi hormat, jadi ada dua hal sekaligus pertama bahwa permohonan itu perkara yang penting menyangkut hidup dan mati orang, yang kedua bahwa niatnya orang itu kuat untuk mohon dikabulkan

d. Maksud mendapatkan pencerahan Orang jawa bilang "golek dalan padang", memohon petunjuk tentang kehidupan pribadi, biasanya berawal dari orang merasa kebingungan mengapa hidupnya tidak sukses selalu usaha gagal atau banyak orang lain melawan dan tidak mendukung, lalu orang bertanya diri apa salah dan dosanya, untuk itu mohon diberi penerangan oleh tuhan supaya supaya hidupnya menjadi berkenan kepadanya . sebenarnya mungkin saja dicobai untuk memperoleh kebersihan dan kesucian melalui proses pembersihan ( katarsis),

\section{GAMBARAN UMUM CANDI HATI KUDUS GANJURAN}

Candi Hati Kudus Ganjuran, bisa dijangkau dengan mengendarai kendaraan bermotor atau mobil kurang lebih $20 \mathrm{~km}$ dari pusat kota Yogyakarta. Pemandang sawah yang hijau dan pohon serupa cemara akan menyambut anda begitu memasuki desa Ganjuran, tempat Candi ini berdiri. Mengunjungi Candi Hati Kudus Tuhan Yesus Ganjuran, anda akan mengetahui tentang sejarah Candi dan inkulturasi Katolik dengan budaya Jawa, terakhir mendapatkan ketenangan hati. Disamping Candi akan kita dapati juga bangunan gereja. Candi Hati Kudus Ganjuran didirikan pada tahun 1927.

\section{Sejarah Candi Hati Kudus Ganjuran.}

Sebelum candi hati kudus ini didirikan kehidupan masyarakat sekitar ganjuran didominasi oleh masyarakat muslim yang taat. Candi Hati Kudus Ganjuran Didirikan oleh keluarga schmutzer yang berasal dari belanda, Keluarga schmutzermerupakan keluarga yang menganut agama katholik pertama kali diganjuran. Candi Hati Kudus Tuhan Yesus Ganjuran dibangun tidak dapat dilepaskan dari keberadaan pabrik gula Gondang lipuro yang dimilki oleh keluarga schmutzer, Oleh penduduk sekitar Keluarga Schmutzer ini dikenal sebagai keluarga yang ramah, suka memberi dan perhatian pada masyarakat sekitar sehingga sangat disegani.Sebagai wujud solidaritasnya, mereka membuka kesempatan kerja, mendirikan sekolahsekolah dan rumah sakit Ganjuran, Karena di daerah Ganjuran belum ada gereja kemudian keluarga Schmutzer membangun gereja Ganjuran, Pada perkembangannya agama Katolik mulai diterima oleh masyarakat Ganjuran dan tidak lama kemudian rata-rata pekerja pabrik gula miliknya memeluk agama Katolik. Hingga kini umatnya terus berkembang namun pada bulan Mei 2006 Gereja ini digunjang gempa, nama Ganjuran diambil dari kisah asmara $\mathrm{Ki}$ Ageng Mangir dan Rara Pembayun yang diasingkan oleh kerajaan Mataram yang mengilhami terciptanya sebuah tembang atau lagu "Kala Ganjur", yang artinya tali pengikat dasar manusia dalam mengarungi kehidupan bersama dengan dasar cinta. Dari lagu tersebutlah nama Ganjuran diperoleh.

\section{Bentuk inkulturasi}

Inkulturasi Budaya Eropa, Jawa, Buddha dan Hindu tertuang pada Candi Hati Kudus Ganjuran, bentuk ikulturasi dapat kita liat pada bangunan candi hati kudus ganjuran.

Candi ini bercorak arsitektur Hindu- 
Jawa (Mataram dan Majapahit) itu mulai dibangun pada 1927 dan diberkati oleh Uskup Jakarta Mgr. van Velsen SJ pada 11 Februari 1930 (tanggal penampakan Bunda Maria di Lordes). Pada saat itu bumi Nusantara juga dipersembahkan kepada Hati Kudus Tuhan Yesus bangunan ini dirancang dengan perpaduan gaya Eropa, Jawa, Buddha dan Hindu. Gaya Eropa dapat ditemui pada bentuk bangunan berupa salib bila dilihat dari udara. Teras candi yang berhias relief bunga teratai ini mengingatkan kita pada ciri khas agama Buddha,Candi ini juga kental bernuansa Kebudayaan Jawa-nya yang dapat kita lihat antara lain:

a. Batu dari candi ini diambil dari Gunung Merapi. Gunung Merapi merupakan salah satu s imbol gunung yang di keramatkan oleh masyarakat Yogyakarta

b. Candi ini menghadap ke pantai laut selatan sebagai simbol penghormatan terhadap penguasa laut selatan yaitu Nyi Roro Kidul

c. Nuansa Jawa juga terlihat pada altar, sancristi (tempat menyimpan peralatan misa), doopvont (wadah air untuk baptis) dan chatevummenen (tempat katekis).

d. Didalamcandisendiribertahtapatung Kristus Raja, lambang kehadiran Tuhan sebagai Bapa. Patung / Arca ini berwujud Tuhan Yesus sebagai Raja dengan berpakaian kebesaran layaknya raja Jawa yang duduk diatas singasana tangan kirinya menyibak pakaian depannya dan tangan kanannya menunjukkan ke arah hatinya yang bersinar.

e. Dan diatasnya tertulis Aksara Jawa yang berarti: "Sampeyan Dalem Maha Prabu Yesus Kristus Pangeraning Bangsa “
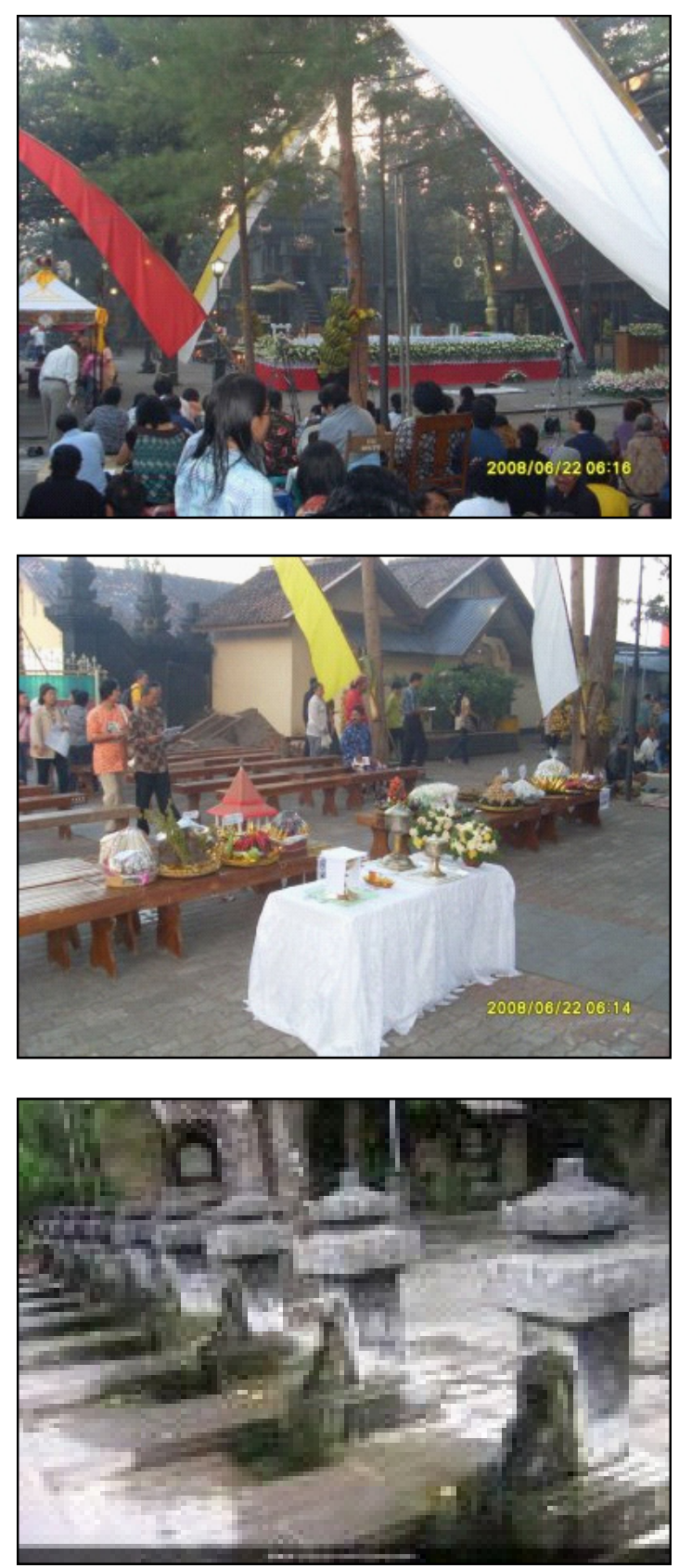

f. Patung Yesus dan Bunda Maria yang tengah menggendong putranya juga digambarkan tengah memakai pakaian Jawa.

g. Demikian pula relief-relief pada tiap pemberhentian jalan salib, Yesus digambarkan memiliki rambut mirip seorang pendeta Hindu.

h. Gaya Jawa bisa dilihat pada atap yang berbentuk tajug, bisa digunakan sebagai atap tempat ibadah. Atap itu disokong oleh empat tiang kayu jati, melambangkan empat penulis Injil, 
yaitu Matius, Markus, Lukas dan Yohanes.

Sedangkan dari Hindu sendiri diwakili dengan adanya patirtan atau petirtaan sebagaimana khasnya seperti kebanyakan candi Hindu lain yang usianyajauh lebih tua dari Candi Ganjuran ini, tidak pernah lepas dari sumber mata air. Karena orang pertama yang disembuhkan bernama Perwita, maka untuk mengenangnya, air berkhasiat itu kini disebut Tirta Perwitasari. Sumber aliran air ini kemudian disalurkan dalam beberapa kran yang berjumlah sembilan, ditempatkan di belakang candi yang dapat dimanfaatkan oleh semua umat. Dibuat sembilan titik kran juga ada maksud tertentu yang disesuaikan dengan tinggi bangunan candi 9 meter dan jumlah tangga naik ke tingkatan Swarloka tempat arca Hati Kudus Yesus bertahta.

Dengan diresamikannya Candi Hati Kudus Tuhan Yesus Ganjuran sebagai tempat ziarah oleh Uskup Agung Semarang, Mgr. I Suharyo Pr, pada 1998, maka terpenuhilah persyaratan tempat ziarah seturut Kitab Hukum Kanonik

\section{PEMBAHASAN}

Analisis minat wisata rohani candi hati kudus ganjuran.menurut sumber dari wawancara yang telah dilakukan yang melakukanwisata rohaniinitidakhanya orang beragama katholik saja tetapi dari berbagai agama, seperti agama Budha, agama Hindu, agama Islam juga melakukan doa dengan cara menurut agama masing dengan berbagai tujuan seperti penyembuhan dari sakit yang telah lama diderita, mencari jodoh, bahkan minta keturunan, menyucikan diri dari ilmu kekebalan, bahkan di setiap malam jumat diadakan misa untuk penyembuhan.misa penyembuhan dilakukan dengan cara tata cara katholik ditambah dengan adat jawa dengan cara mengambil air lalu didoakan dan akhirnya ada upacara arak-arakan, berikut ini adalah gambar prosesi untuk misa penyembuhan.

Prosesi dilakukan dengan cara arakarakan dan menyemprotkan air yang diambil dari air perwita sari kepada orang yang membutuhkan bahkan ada yang membawa pulang air tersebut. Menurut sumber dengan cara wawancara langsung untuk mengetahui minat mengapa mereka mengujungi ganjuran adalah melakukan permohonan dan ucapan syukur atas terkabulnya doa mereka sehingga makin banyak orang yang datang kesana untuk memohon, berikut ini adalah beberapa kesaksian yang sudah minum air perwita sari candi ganjuran,

\section{Kesaksian}

\section{Air Perwitasari' Candi Ganjuran}

Ketika perang kemerdekaan berkecamuk, hampir di mana saja kolonial Belanda menerapkan taktik bumi hangus. Begitu pula ketika berlangsung perlawanan seru di Ganjuran, Bantul, Jogyakarta. Daerah ini sempat dihujani bom hingga menghancurkan sebuah pabrik gula. Eloknya, ada sebuah candi kecil luput dari ledakan bom, siraman mortir dan jilatan api. Padahal hanya berada belasan meter dari pabrik yang berubah jadi karang abang itu. Candi itu bernama 'Candi Hati Kudus Yesus'. Kini banyak diziarahi tidak saja dari penduduk lokal, tapi juga dari luar negeri. Dijadikan alternatif atau tumpuan untuk mendapatkan berkah kesembuhan.

Candi di Ganjuran tersebut memang bukan peninggalan kuna, tapi terbukti merupakan bangunan sakral seperti candicandi purbakala. Buktinya, bisa selamat dari amukan angkara murka. "Padahal terbakarnya amat hebat, pembomannya pun seru," menurut sumber dari Sukardi, pengurus sekretariat Candi meneruskan cerita leluhur. Saat diwawancara, dia tengah 
melayani rombongan bermobil dengan plat nomor DK (Denpasar). Candi tersebut memang unik. Didirikan van Driesche SY dan bercorak Hindu Jawa, dibangun sebagai ungkapan syukur atas berkat Tuhan yang melimpah pada tahun 1927. Peresmiannya dihadiri banyak umat dan seluruh pemimpin religius dari berbagai pelosok tanah air pada 1930. Sementara pemberkatannya dilaksanakan 11 Februari, tepat dengan tanggal penampakan Maria di Lourdes. Dengan begitu digenapilah kerinduan umat Katolik yang mencari Tuhannya melalui Maria.

Pelataran candi relatif luas, biasa untuk menggelar upacara tradisional Jawa. Bila candi Hindu biasa menghadap ke Timur, candi Tyas Dalem Sri Yesus ini menghadap ke Selatan. Mempunyai tingkatan dengan apa yang disebut sebagai Swarloka, atau kahyangan. Untuk masuk ke tempat persemadian di mana arca Tyas Dalem berada, harus lewat 9 tangga sebagai simbolisasi 'nutupi babahan hawa sanga'.

Lokasinya diteduhi banyak pohon cemara, sawo kecik dan keben. Suasana sakral begitu kental. Batu-batu yang tertata menjadi bangunan candi pun unik pula. Ada satu batu candi berkisah unik. Berbeda dengan batu-batu lainnya.

Diyakini, tidak ada yang kuat tidur di samping batu candi itu. Bentuk prasastinya pun khas, menyimpan cerita yang sulit dipercaya. Sejak 1990, nilai-nilai budaya Jawa dikembangkan dan digali dalam nuansa religius oleh Gereja Katolik. Rahmat itu bertambah ketika tahun 1998 ditemukan sumber mata air besar di bawah candi.

Dalam penelitian di laboratorium air di bawah candi ini mengandung mineral tinggi. Oleh karenanya air ini kemudian dinaikkan agar bermanfaat. Kebetulan yang memakai air itu pertama kali adalah seseorang bernama Perwita yang tengah menderita sakit. Karena imannya Pak Perwita merasakan daya penyembuh air candi ini. Untuk mengenang penemuannya air candi itu diberi nama Tirta Perwitasari.

Secara kebetulan di dalam dunia pewayangan disebut pula air suci Perwitasari yang diburu oleh Wijasena, sebagai air kehidupan.Secara gethok tular berkah dan tuah air itu meluas. Lalu banyak yang memanfaatkannya. Bahkan kini, pencari kesembuhannya berasal dari berbagai kota di tanah air. Pada hari-hari tertentu, seperti Jumat Kliwon atau pun Jumat pertama tiap bulan, candi itu banyak dikunjungi peziarah. Pada malam sebelumnya, biasanya diselenggarakan misa dengan iringan gamelan dan tradisi Jawa yang kental.

Ketika pulang, para peziarah biasanya membawa air Perwitasari dengan keyakinan air ini memberi banyak manfaat dalam kehidupannya. Kesaksian tentang mukjizatnya bisa disimak dari buku tamu. Misal : 'Terima kasih Tuhan'. Demikian tulis Maria dari Jakarta. Lama dia menderita sakit, akhirnya mendapat kesembuhan setelah telaten meminum air Perwitasari. Demikian pula dialami Hadiman Sutejo, penderita sakit telinga ini mengaku sembuh setelah meminum air Perwitasari 'Candi Tyas Dalem’ di Ganjuran Bantul.

Kejadian serupa juga dialami Savitri, warga Ganjuran. Alerginya yang menahun bisa sembuh setelah meminum air tersebut. Kalau Tuhan menghendaki, apa pun memang bisa menjadi perantara. Demikian halnya dengan Yarmani warga Pati yang telah lima tahun menderita kanker, juga sembuh dengan doa dan air Perwitasari. Setumpuk kesaksian dalam buku tamu merupakan bukti nyata keampuhan tuah air Perwitasari Candi Ganjuran. Contoh lainnya, seorang lelaki yang sudah beberapa tahun mengidap kencing darah, mengaku sembuh total lantaran meminum air Perwitasari dari Ganjuran ini. Demikian pula Suparti yang Anemia dan tadinya HB darahnya 5 kini sudah normal dan sehat. Hal sama dialami Caecilia dan Nuke dari Kadipaten, demikian 
pula Bambang dari Lamper Sari Semarang.

Itulah cuplikan dari berbagai kesaksian yang sempat ditulis oleh pelakunya sendiri. Dan yang datang ke Candi ini begitu beragam dari berbagai kota di Jawa seperti Jakarta, Sukabumi, Bandung, Semarang, Magelang, Klaten, Solo, Surabaya, Malang dan sebagainya. Bahkan mereka juga berasal dari berbagai keyakinan dan agama. Pengurus Candi sering kaget mendengar laporan dari para peziarah yang datang ke candi bergaya Hindu Jawa. Inilah sebuah inkulturasi budaya yang khas Jawa.

\section{KESIMPULAN}

Dari analisis yang didapatkan terdapat minat wisata rohani di candi hati kudus ganjuran dengan berbagai tujuan, ada yang mencari kesembuhan, ada yang mencari pengharapan, ada yang mencari ketenangan hati, bahkan kaum muda ada yang memohon untuk mendapatkan jodoh, ada juga yang mengungkapkan syukur atas apa yang telah diberikan oleh tuhan.

\section{DAFTAR PUSTAKA}

Gunarso,S. 1995. Psikologi Remaja. Yogyakarta :Andi Offset
Hurlock, B, Elizabeth 1995.Perkembangan Anak. Jakarta: Erlangga

Kamisa,1997. Kamus Bahasa Indonesia. Surabaya: Kartika

Notoatmojo, 1997. Metodologi Penelitian Kesehatan. Jakarta : Rineka Cipta

Nursalam 2003. Konsep Dan Penerapan Metodologi Penelitian Ilmu Keperawatan. Jakarta : Salemba Medika

Romo Gregorius Utomo 2012. Gereja hati kudus Yesus diganjuran. Yogyakarta : Unggul Jaya

Usman Effendi dan Juhaya S Praja, 1993. Pengantar psikologi. Bandung: Angkasa

Undang-undang Kepariwisataan nomor 9 tahun 1990

Yuwono, 2001 : Prilaku organisasi. Yogyakarta : Andi offset

Witherington, 1999. Psikologi Pendidikan. Jakarta : Aksara Baru

WS Winkel, 1986. Psikologi Pendidikan Dan Evaluasi Belajar. Jakarta: Gramedia 